\begin{tabular}{|l|l|l||}
\hline \multicolumn{2}{|c|}{ PublisherInfo } \\
\hline \hline PublisherName & $:$ & BioMed Central \\
\hline \hline PublisherLocation & $:$ & London \\
\hline \hline PublisherImprintName & $:$ & BioMed Central \\
\hline \hline
\end{tabular}

\title{
Chemokine receptor and cytokine profiles in juvenile arthritis
}

\begin{tabular}{|l|l|l||}
\hline \multicolumn{2}{|c|}{ ArticleInfo } \\
\hline \hline ArticleID & $:$ & 181 \\
\hline \hline ArticleDOI & $:$ & $10.1186 /$ ar-2000-66812 \\
\hline \hline ArticleCitationID & $:$ & 66812 \\
\hline \hline ArticleSequenceNumber & $:$ & 138 \\
\hline \hline ArticleCategory & $:$ & Paper Report \\
\hline \hline ArticleFirstPage & $:$ & 1 \\
\hline \hline ArticleLastPage & $:$ & 3 \\
\hline \hline & $:$ & RegistrationDate : 2000-5-26 \\
\hline ArticleHistory & $:$ & OnlineDate \\
\hline \hline ArticleCopyright & $:$ & Current Science Ltd2000-5-26 \\
\hline \hline ArticleGrants & $:$ & \\
\hline \hline ArticleContext & $:$ & 130753311 \\
\hline \hline
\end{tabular}


Oliver Fitzgerald, ${ }^{\text {Aff1 }}$

Aff1 St Vincent's University Hospital, Dublin

\section{Keywords}

Chemokines, cytokines, juvenile inflammatory arthritis

\section{Context}

Factors involved in migration of $\mathrm{T}$ cells into the inflamed synovium of children with juvenile idiopathic arthritis (JIA) have not previously been characterised. Selective recruitment across a chemokine gradient may result in migration of specific subsets of T cells which could in turn contribute to a cytokine imbalance within the synovial tissue. The chemokine receptors CCR5 and CXCR3 are expressed on activated T cells with a type I cytokine profile. To study the expression of CCR5 and CXCR3 and Th1/Th2 cytokine balance in children with JIA.

\section{Significant findings}

Twenty JIA patients were studied, eleven with persistent oligoarticular arthritis, five with extended oligoarticular disease and four with polyarticular arthritis. Levels of expression of CCR5 were significantly higher on SF-derived T cells as compared to PB cells. This applied to the CD3 ${ }^{+}, \mathrm{CD}^{+}{ }^{+}$and $\mathrm{CD} 8{ }^{+}$populations. The expression of CXCR3 was more variable. All SF T cells expressed CCR5; 75\% also expressed CXCR3 at high levels, with the remaining 25\% expressing CXCR3 either at low levels or not at all. One patient showed no expression of CCR5 protein and was found to be homozygous for the Null ?32CCR5 allele. In relation to cytokine production, SF T cells displayed a Th1 pattern with markedly higher IFN-? production compared to that in PB. There was a mean 6.1-fold increase in the IFN-?/IL-4 ratio. Finally, cytokine receptor expression and Th1-type cytokine production were found in particular on SF-derived T cells expressing CD45RO.

\section{Comments}


These findings are similar to those previously described for other forms of chronic inflammatory arthritis. There is a suggestion of different patterns emerging in patients with persistent oligoarticular versus polyarticular disease. Expansion of patient numbers might prove informative. Finally, as events within the synovial fluid (SF) compartment may not be representative of events in synovial tissue, these studies should be extended to synovial membrane samples.

\section{Methods}

Chemokine receptor expression (CCR5 and CXCR3) and Tcell cytokine production (interferon [IFN]? and IL-4) by paired samples of synovial fluid (SF) and peripheral blood (PB) T cells from 20 patients with JIA were studied using three colour immunofluorescence. The same analysis was performed on subsets of T cells expressing CD45RO. Finally, CCR5 genotypes were confirmed by PCR and sequencing.

\section{References}

1. Weederburn LR, Robinson N, Patel A, Varsani H, Woo P: Selective recruitment of polarised T cells expressing CCR5 and CXCR3 to the inflamed joints of children with juvenile idiopathic arthritis. Arthritis Rheum. 2000, 43: 765-774.

This PDF file was created after publication. 